\title{
Original article (full paper) \\ Aging male symptoms: the relationship between physical activity and quality of life
}

\author{
Melissa de Carvalho Souza \\ Adriana Coutinho de Azevedo Guimarães \\ Universidade do Estado de Santa Catarina, UDESC, Florianópolis, SC, Brasil
}

\begin{abstract}
Objective To examine the relationship between physical activity (PA) and the aging male symptoms of middle-aged men in the quality of life (QOL). Methodology: Cross-sectional study with a probabilistic samples of 416 men (40-59 years old), all residents in two cities in southern of Brazil. A questionnaire was used. The studied population was divided into two groups: with and without symptoms. The analyses were carried out in a descriptive and inferential approaches. Results: Aging male symptoms were related to QOL. Men who perceive their overall QOL as good presented a $13 \%$ lower probability of $(95 \% \mathrm{CI}=0.77-0.98)$ being insufficiently active. For those with symptoms, QOL scores were higher in social and environmental domain in PA between 30-60 min/day, and the physical domain for more than $60 \mathrm{~min} /$ day. Conclusion: Our findings show the importance of PA to achieve significant benefits in QOL and health of men in middle age with aging male symptoms.
\end{abstract}

Keywords: motor activity, quality of life, men, male ageing, health

\section{Introduction}

Middle age can be understood as a process of transition between adulthood and old age, including the age group from 40 to 59 years (Andrews, 2000). At this stage, physiological, morphological, and physical changes occur which appear distinctly in men and women (Antunes \& Silva, 2013). For several years the characteristics of this stage in women (known as menopause) have been well documented, either being their effects on health as well as on the quality of life (KrajewskaFerishah et al., 2010; Waidyasekera, Wijewardema, Lindmark $\&$ Naessen, 2009). However, only in the years 2000 literature has been directing their studies more profoundly towards the modifications of the male population (Rohden, 2012). Such processes in men begin from about 40 years of age, along with symptoms, which are classified into; psychological symptoms including anxiety, depression, depressed mood, irritability and nervousness, sexual dysfunction with decreased ability/frequency of sexual activity, reduction in the number of morning erections, and decreased libido, and somatic symptoms with declining sense of well-being, decreased muscle strength, muscle and joint pain, insomnia and physical exhaustion. These symptoms may appear in mild, moderate or severe intensity (Heinemann, 2005).

According to some authors the prevalence of these symptoms affects the quality of life of men, even at lower intensities, considering the physical, psychological, social, and environmental domains (Salazar, Paravic \& Barriga, 2012; Staerman \& Léon, 2012). Regarding the aging process, quality of life is determined by the ability to maintain autonomy, decision-making, independence and ability to perform daily tasks (Freitas, Queiroz \& Sousa, 2010), its decline may contribute to the risk of chronic degenerative diseases in different populations, mostly in men over the age of 40 years (Martits \& Costa, 2004). Thus, it is important to maintain adequate levels of quality of life in this population (Perchon, Pintarelli, Bezerra, Thiel \& Dambros, 2011).

Thus, clinical measures, such as hormone replacement, have been addressed to improve the quality of life of men experiencing aging symptoms, as well as for the lower prevalence of this symptomatology (Rohden, 2012). Other studies highlight the importance of the practice of physical activity as another measure to ease the symptoms, given its relevance to the physical, psychological and sexual aspects (Corrêa, Rombaldi \& Silva, 2011; Corrêa, Silva \& Rombaldi, 2014).

Recently, the practice of at least 150 minutes/week, according to the recommendations of the World Health Organization [WHO] (2011), was associated with a lower prevalence of symptoms, and the intensity in which they occur (Corrêa et al., 2014). However, the influence of physical activity is still unknown, considering intensity and duration on quality of life in their domains, specifically, in men who are in the process of the aging symptoms. In addition, these symptoms have already reached a prevalence of over $40 \%$ in Brazilian middle-aged men up to the sixth decade of life (Abdo \& Afif-Abdo, 2007). Unfortunately, only approximately $30 \%$ of men receive clinical diagnosis (Sociedade Brasileira de Urologia, SBU, 2012). Thus, it is important to investigate the influence of physical activity in these symptoms as well the health and quality of life of men, in order to contribute to the health promotion of this particular population. Thus, the present study aimed to verify the relationship between physical activity and quality of life according to the aging symptoms in middle-aged men. 


\section{Methodology}

\section{Study characterization}

The exploratory analytical observational study with a cross-sectional delineation, consisted of middle aged men, within the age group of 40 to 59 years (Andrews, 2000), all residents in the greater Florianópolis region, located in the South of Brazil. The Ethics Committee on Human Research (CEPSH) of the Santa Catarina State University approved the study, Protocol number 535,729.

\section{Population and sample}

The cities were selected from the Greater Florianópolis area with more than 200 thousand inhabitants who presented similar economic characteristics, according to the last census by the Brazilian Institute of Geography and Statistics [IBGE] (2010). Corresponding to the cities of Florianopolis and São José, with a male population of 51,740 and 20,939 , respectively, within the age group 40 to 59 years; thus, the study population was comprised of 72.679 men.

The population was stratified in conglomerates of socioeconomic status according to the IBGE (2010), having as base the minimum wage (MW) of $\mathrm{R} \$ 724,00$ valid in 2014. The individuals were classified as class A (above $20 \mathrm{MW}$ ); class B (10 to $20 \mathrm{MW}$ ); class C (4 to $10 \mathrm{MW}$ ); class D (2 to $4 \mathrm{MW}$ ) and class $\mathrm{E}$ (up to $2 \mathrm{MW}$ ).

In order to define the sample size, $20 \%$ was adopted on prevalence of male aging symptoms for men with age equal to or superior to 40 years (Heinemann, Zimmermann, Vermeulen, Thiel \& Hummel, 1999), a four percentage point tolerable error, a 95\% confidence level, and a 1.5 design effect (Luiz \& Magnanini, 2000). Possible losses and refusals were increased to $10 \%$, considering $631 \mathrm{men}$ in the final sample. In accordance with the calculation in proportion to each socioeconomic class, the outcome showed 31 men belonging to class A, 193 to class B, 205 to class C, and 202 to class D following IBGE, neighborhoods considered to be class $\mathrm{E}$ were not characterized by the census for being sectors with low household density.

Research subjects presenting some clinically diagnosed sickness, such as cancer, cardiovascular diseases, diabetes, hypertension, and paraplegias, as well as institutionalized subjects (nursing homes, prisons, hospitals, and barracks), and those who presented inability to understand the questionnaire (mental illnesses).

In total 1,150 households were contacted, and in 338 households did not have men aged 40 to 59 . During the data collection process, there were occasions of 396 refusals. Thus, the final sample by conglomerate random was of 416 men within the age of $49 \pm 6$ years, 24 from class A, 89 from class B, 234 from class C, and 69 from Class D.

While the sample obtained was not sufficient to meet the accuracy specifications previously established in this study, this represented more than a half $(66 \%)$ of 631 subjects provided in the final sample. The 416 men in the study would be sufficient considering a five percentage point tolerable error. Furthermore, a randomization process was observed in the sample selection.

\section{Research Tools}

For data collection in this study, a questionnaire was used divided into seven parts.

\section{Sample Characteristics}

Information related to age, marital status, schooling, occupation, presence of clinically diagnosed disease, use of medicines for both disease and sexual performance, and tobacco consumption.

\section{Anthropometric Measurements}

Body weight and stature (self referred) for body mass index - BMI (weight/stature ${ }^{2}$ ). For the BMI classification (weight status), the World Health Organization [WHO] (2004) protocol with the cut off points below:

Underweight $(\mathrm{BMI}<18.5)$; regular weight (BMI within 18.5-24.9); overweight (BMI within 25.0-29.9), and obesity $(\mathrm{BMI} \geq 30.0)$. Underweight and regular weight categories were set into regular weight; and overweight and obesity categories were set into overweight, due to the low frequency of subjects within the underweight and obesity categories.

\section{Socioeconomic Status}

IBGE (2010) classifications were used to categorize individuals into socioeconomic status. Such classifications into socioeconomic strata A, B, C, D, and E, was carried out by means of the average monthly family income, in particular, class A (above $20 \mathrm{MW}$ ), class B (10 to $20 \mathrm{MW}$ ), class C (4 to $10 \mathrm{MW}$ ), class $\mathrm{D}$ ( 2 to $4 \mathrm{MW}$ ), and class $\mathrm{E}$ (up to $2 \mathrm{MW}$ ).

For data analysis, the strata were set in high class (A and B), middle class (C), and lower class (D and E).

\section{Physical Activity}

The International Physical Activity Questionnaire (IPAQ Short version) was adopted for assessment of physical activity. In Brazil, that questionnaire was validated by the Center of Studies of the Physical Fitness Research Laboratory in São Caetano do Sul-CELAFISCS, which is the IPAQ coordinator center in Brazil (Pardini, et al., 1997). The Brazilian validity and reproducibility had significantly high Spearman correlation (rho=0.69-0.71: $p<0.001$ ) (Matsudo et al., 2001). In the current physical activity evaluation through IPAQ, the number of times in which an individual carried out at least 10 minutes of continuous walking, moderate intensity physical activity, 
and vigorous intensity physical activity was observed in the last week, in various involvements, in particular, labor, home, leisure, sports, and recreation. Physical activity was classified into walking, moderate, moderate+vigorous, vigorous, and total physical activity in minutes/day.

Thus, the individuals were classified as: insufficiently active - those who practiced at least 10 minutes of continuous physical activities per week, however, insufficient for classification as active. The sum of the duration and frequency of the different activities (moderate vigorous walking) is performed to establish the following criteria: active - has complied with the following recommendations: a) vigorous physical activity $\geq 3$ days/week and $\geq 20$ minutes/session; b) moderate $\geq 5$ days/week and $\geq 30$ minutes /session; c) any combined activity: $\geq 5$ days/week and $\geq 150 \mathrm{~min} /$ week; very active - has fulfilled the indications: a) vigorous $\geq 5$ days/week and $\geq 30 \mathrm{~min} /$ session; b) vigorous $\geq 3$ days/week and $\geq 20 \mathrm{~min} / \mathrm{session}$ moderate $\geq 5$ days/week and $\geq$ $30 \mathrm{~min} / \mathrm{session}$. The individuals were set into sufficiently active (active+very active) and insufficiently active.

IPAQ - short version was used, since it is suitable for monitoring the level of physical activity, producing comparable results to the long version (Craig et al., 2003).

\section{Health Perception}

Health perception was evaluated following the question model contained in BRFSS - Behavioural Risk Factors Surveillance System Questionnaire [CDC] (1999). It is composed of an issue that evaluates the individual's health perception. The answers are in a "Likert scale", in which 1 represents excellent; 2 very good; 3 good; 4 regular; 5 bad. For data analysis, due to the low presence of individuals in the categories excellent, good, and regular, answers 1 to 3 were set as very good and the answers 4 and 5 as bad.

\section{Aging Male Symptoms}

Aging Male Symptoms Scale (AMS) was used in a Portuguese version (Heinemann et al., 2003). The reliability values of this version were significantly higher in the Pearson correlation considering the total score $(r=0.74)$ and the score of psychological and sexual symptoms $(r=0.67)$. For the score of somatic symptoms the correlation coefficient was considered lower ( $r=0.45$ ) (Daig et al., 2003). The scale is composed by 17 questions divided into three symptom blocks: psychological (five issues), somatic (7 questions), and sexual symptoms (five issues). The sum of the issues, which results variation from one to five points was considered as the general symptom score (Heinemann et al., 1999). The general score for somatic, psychological, and sexual symptoms were categorized, being classified as having psychological symptoms the subjects who obtain scores $\geq 12$ points; with somatic symptoms, the subjects who have scores $\geq 13$ points; and with sexual symptoms those subjects who have scores $\geq 8$ points. The general symptom score was dichotomized so that those who submit score $\geq 27$ points were classified as having aging symptoms, while those with values below that score were classified without symptoms. The general score of male aging symptoms was also categorized so that those who submit score between 27 and 36 points were considered as having "smooth/mild symptoms"; those with a score between 37 to 49 points, considered as having "moderate" symptoms; and those with a score equal to or greater than 50 , as having "severe symptoms" (Heinemann et al., 1999). For the purposes of analysis the participants were divided into two groups: subjects with symptoms and without symptoms.

\section{Quality of Life}

Evaluated through World Health Organization Quality of Life (WHOQOL) short questionnaire, which is adapted to Portuguese of Brazil (Fleck et al., 1999). This is a questionnaire is composed of 26 issues (of the original 100). There are 24 questions concerning the physical domain (physical pain, energy, mobility, daily living activities, medical treatment, work), psychological (positive feelings, concentration, self-esteem, self-image, negative feelings, spirituality), social (personal relationships, social support, sexual activity) and environment (physical security, housing, financial, healthcare, information, leisure, physical environment and transport) and two more general questions about quality of life. The result provides scores for each domain ranging from 0 to 100 points, the closer to 100 , the better the quality of life score. The issue related to the overall quality of life was categorized according to the answers: very bad; bad; neither good nor bad; good; and very good, according to studies previously published (Conceição et al., 2012; Pereira, Teixeira \& Lopes, 2013). In this study, due to the low response in very bad; neither bad nor good, very good categories, they are grouped into: bad and good. The instrument showed adequate internal consistency, the amount of Cronbach's coefficient for the domains was 0.77 . For discriminant validity, the control subjects showed higher scores in each of the four domains (physical $=16.6 \pm 2.1,15.6 \pm 2.1=$ psychological, social $=15.5 \pm 2.6$; environmental $=14.0 \pm 2.1)$. Regarding the criterion validity they all showed a significant correlation $(p<0.001)$ (Fleck et al., 2000).

\section{Data Collection}

A team of seven individuals of both genders, holding at least complete high school education, carried out data collection. This team received 40 hours of training for application of the instrument from the main researcher of the study. In this training each question of the instrument was explained as well how to approach the subject and apply the questionnaire. After the procedure, questionnaires were forwarded for data collection. Interviewers conducted the interviews individually.

The zip code draw was held proportionally considering the four socioeconomic strata (A, B, C, and D) of the neighborhoods of Florianópolis and São José. The zip codes of each district were registered in a spreadsheet in the Excel program version 
2010. The same program is currently used mostly for the draw of the zip codes of each district of the socioeconomic strata.

Thus, the streets corresponding to the zip codes were visited and the first home of the street was selected to be included in the study. The interval between the houses was in accordance with the quantity of households found in every street in which men aged 40 to 59 years could be found. The domicile was considered excluded from the study after the third failure to contact, and was also excluded when the individual refused to participate in the study. This process was replicated in all socioeconomic strata

The study questionnaire was applied in the format of an interview. In the block of sexual symptoms of the male aging symptoms scale, the participant had the option to answer individually if feeling uncomfortable or simply continue the interview.

\section{Statistical Analysis}

Statistical analysis was carried out using the Statistical Package for Social Sciences (SPSS) version 20.0, and Bioestat version 5.3. Descriptive statistics were used by means of the mean calculation, standard deviation, and percentage. The normality of the data was checked using the Kolmogorov-Smirnov test. The associations of personal characteristics among men with and without symptoms were carried out through the Chisquare test. The comparison of quality of life domains (physical, psychological, social, and environmental) among men with and without symptoms has been carried out through the MannWhitney $U$ test. The comparison of the domains of quality of life and the characteristics of the sample was done by means of the Mann-Whitney U, and Kruskal-Wallis tests. The comparison between the three groups of physical activity (Group A $<30 \mathrm{~min} /$ day; Group B 30-60 min/day; Group C >60 min/day) with the averages of the domains of quality of life was performed by Kruskall-Wallis test followed by the post hoc Student-NewmanKeuls. Multinomial Logistic Regression Analysis was performed to estimate raw and adjusted odds ratios between the levels of PA (dependent variables) and aging male symptoms and overall quality of life outcomes (independent variables). A simple and multiple models have been tested (adjusted for all variables). In the whole analysis, the significance adopted was the level of $5 \%$.

\section{Results}

Table 1 presents the characteristics of participants among men with and without aging male symptoms. The significant variable differences were presented in the use of medicines for diagnosed diseases, health perception and physical activity level ( $p=0.032 ; p$; $p=0.0010 .026<$ ), respectively. Men without symptoms presented lower use of drugs for diseases $(92.5 \%)$, better health perception $(92.5 \%)$ and sufficient levels of physical activity $(66.9 \%)$.

Table 1. Characteristics of the sample according to the men symptomatology (\%). Florianópolis and São José 2014. ( $\mathrm{n}=416)$

\begin{tabular}{|c|c|c|c|c|c|}
\hline & With Symptoms & IC95\% & Without Symptoms & IC95\% & p Value \\
\hline Age & & & & & 0.395 \\
\hline $40-49$ years & 59.3 & $39-51$ & 40.7 & $42-57$ & \\
\hline $50-59$ years & 63.3 & $49-61$ & 36.7 & $43-58$ & \\
\hline Schooling & & & & & 0.265 \\
\hline Elementary School & 14.8 & $10-19$ & 9.4 & $05-14$ & \\
\hline Secondary School & 30.9 & $25-37$ & 32.5 & $25-40$ & \\
\hline Higher Education & 33.4 & $48-60$ & 22.4 & $50-66$ & \\
\hline Socioeconomic Status & & & & & 0.287 \\
\hline High & 36.5 & $31-42$ & 39.4 & $32-47$ & \\
\hline Medium & 33.3 & $28-39$ & 37.5 & $30-45$ & \\
\hline Low & 30.2 & $25-36$ & 23.1 & $17-30$ & \\
\hline \multicolumn{6}{|l|}{ Profession } \\
\hline Self-employed & 58.8 & $52-65$ & 61.6 & $54-69$ & 0.646 \\
\hline Retired & 4.6 & $02-07$ & 2.6 & $0-05$ & \\
\hline Civil Servant & 36.2 & $30-42$ & 35.8 & $28-43$ & \\
\hline \multicolumn{6}{|l|}{ Marital Status } \\
\hline Living together & 80.7 & $76-86$ & 83.8 & $78-90$ & 0.434 \\
\hline Living apart & 19.3 & $14-24$ & 16.2 & $10-22$ & \\
\hline \multicolumn{6}{|l|}{ Sickness Presence } \\
\hline Yes & 20.7 & $16-26$ & 14.4 & $09-20$ & 0.104 \\
\hline No & 79.3 & $74-84$ & 85.6 & $80-91$ & \\
\hline Sickness Medicine & & & & & 0.032 \\
\hline Yes & 14.5 & $10-19$ & 7.5 & 03-12 & \\
\hline No & 85.5 & $81-90$ & 92.5 & $88-97$ & \\
\hline Sexual Medicine & & & & & 0.258 \\
\hline Yes & 2.3 & $0-04$ & $0.6^{*}$ & $-01-02$ & \\
\hline No & 97.7 & $96-100$ & 99.4 & $98-100$ & \\
\hline
\end{tabular}


Table 1. Continued.

\begin{tabular}{|c|c|c|c|c|c|}
\hline & With Symptoms & IC95\% & Without Symptoms & IC95\% & p Value \\
\hline Weight Status & & & & & 0.636 \\
\hline Regular weight & 27.8 & $22-33$ & 30.0 & $23-37$ & \\
\hline Overweight & 72.2 & $67-78$ & 70.0 & $63-77$ & \\
\hline Health Perception & & & & & $<0.001$ \\
\hline Very good & 77.0 & $72-82$ & 92.5 & $88-97$ & \\
\hline $\mathrm{Bad}$ & 23.0 & $18-28$ & 7.5 & $03-12$ & \\
\hline \multicolumn{6}{|l|}{ Tobacco Smoking } \\
\hline Yes & 12.5 & $08-17$ & 16.2 & $10-22$ & 0.283 \\
\hline No & 87.5 & $83-92$ & 83.8 & $78-90$ & \\
\hline PA Level\# & & & & & 0.026 \\
\hline Insufficiently active & 44.1 & $38-50$ & 33.1 & $26-40$ & \\
\hline Sufficiently active & 55.9 & $50-62$ & 66.9 & $60-74$ & \\
\hline
\end{tabular}

Teste do Qui-squared. $\bar{x}(\mathrm{sd})$ : mean (standard deviation).

*Fisher Exact. \#Physical Activity.

Even though significant difference could not be observed in other variables, the subjects without aging male symptoms, were mostly $40-49$ years old (40.7\%), high school graduates $(32.5 \%)$, belonging to a high socioeconomic class $(39.4 \%)$, self-employed (61.6\%), living with a companion $(83.8 \%)$ not presenting disease $(85.6 \%)$, not using medicine for sexual performance $(99.4 \%)$, within regular weight $(30 \%)$, and non-smokers $(83.8 \%)$.

The results of the comparison of the mean of the quality of life score between men with and without aging male symptoms are presented in Table 2. Significant results were observed in all the variables $(p<0.001)$, demonstrating that men without symptoms showed higher average scores in all areas of quality of life $(63 \pm 8 ; 69 \pm 8 ; 77 \pm 12 ; 71 \pm 11)$.

In a comparison between the mean of the quality of life domains and the sample characteristics, the age group showed significant difference with only the physical domain, and individuals from 50 to 59 showed higher mean scores $(61 \pm 8 ; p=0.004)$. The men with higher education and belonging to the high socioeconomic classes, require higher means in the psychological and environmental domain $(67 \pm 9 ; p=0.010$ e $69 \pm 12 ; p<0.001)$, concurrently. As for the PA level, sufficiently active men presented higher mean scores in the physical and psychological domains $(61 \pm 8 ; p=0.003$ e $67 \pm 9 ; p=0.048)$ (date not presented in the table).

Table 2. Comparison of quality of life between men with and without aging symptoms (mean and standard deviation). Florianópolis and São José 2014. $(\mathrm{n}=416)$

\begin{tabular}{|c|c|c|c|c|c|c|}
\hline & Median & Interquartile range & Total & $\begin{array}{c}\text { With Symptoms } \\
\overline{\mathbf{x}}(\mathbf{s d})\end{array}$ & $\begin{array}{c}\text { Without Symptoms } \\
\overline{\mathbf{x}}(\mathbf{s d})\end{array}$ & p Value \\
\hline Physical Domain & 61 & 14.29 & $60(9)$ & $58(9)$ & $63(8)$ & $<0.001$ \\
\hline Psychological Domain & 67 & 8.33 & $65(9)$ & $63(10)$ & $69(8)$ & $<0.001$ \\
\hline Social Domain & 75 & 8.33 & $71(15)$ & $67(16)$ & $77(12)$ & $<0.001$ \\
\hline Environmental Domain & 68 & 17.86 & $66(13)$ & $63(13)$ & $71(11)$ & $<0.001$ \\
\hline
\end{tabular}

Descriptive statistic. U deMann-Whitney Test

A comparison of the mean scores of quality of life domains with the intensities of physical activity in men with male aging symptoms is represented in Table 3. Quality of life scores were observed higher in social (72 \pm 14$)$ and environmental $(66 \pm 11)$ areas in the practice of physical activity at moderate intensity for the men of group B, in comparison to the other groups. In the moderate+vigorous physical activity, the mean scores of the physical domain were higher for group $C(59 \pm 8)$, and the environmental field for the men of group B $(66 \pm 12)$. Whereas at total physical activity practice, the scores on the physical domain

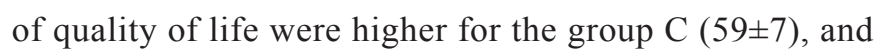
the social and environmental fields for the men of group B $(70 \pm 13 ; 66 \pm 12)$.

Table 4 presented the associations of physical activity level with aging male symptoms and overall quality of life. In the simple model the physical activity level was associated with both variables. When the model had been adjusted, only the overall quality of life remained associated. Men who perceive their overall quality of life as good presented a $13 \%$ lower probability $(95 \% \mathrm{CI}=0.77-0.98)$, of being insufficiently active. 
Table 3. Comparison of the averages of scores of quality of life domains with the intensity of physical activity of men with aging symptoms (mean and standard deviation). Florianópolis and São José, SC. 2014. (n=256)

\begin{tabular}{|c|c|c|c|c|c|c|c|c|c|c|c|c|}
\hline & & & $\begin{array}{c}\text { PA } \\
\text { ODERA] }\end{array}$ & & & MO & DERATH & VIGOR & US & & $\begin{array}{c}\text { PA } \\
\text { TOTAL }\end{array}$ & \\
\hline & $\begin{array}{c}\text { Group } \\
\text { A }\end{array}$ & $\begin{array}{c}\text { Group } \\
\text { B }\end{array}$ & $\begin{array}{c}\text { Group } \\
\text { C }\end{array}$ & $\begin{array}{c}p \\
\text { value }\end{array}$ & $\begin{array}{c}\text { Group } \\
\text { A }\end{array}$ & $\begin{array}{c}\text { Group } \\
\text { B }\end{array}$ & $\begin{array}{c}\text { Group } \\
\mathrm{C} \\
\end{array}$ & $\begin{array}{c}\mathbf{p} \\
\text { Value }\end{array}$ & $\begin{array}{c}\text { Group } \\
\text { A }\end{array}$ & $\begin{array}{l}\text { Group } \\
\text { B }\end{array}$ & $\begin{array}{c}\text { Group } \\
\text { C }\end{array}$ & $\begin{array}{c}p \\
\text { Value }\end{array}$ \\
\hline $\begin{array}{l}\text { Physical Do- } \\
\text { main } \bar{x}(\mathrm{sd})\end{array}$ & $57(9)$ & $59(8)$ & $58(8)$ & 0.476 & $56(10)^{\mathrm{c}}$ & $57(9)^{\mathrm{c}}$ & $59(8)^{\mathrm{a} . \mathrm{b}}$ & 0.018 & $55(10)^{\mathrm{c}}$ & $56(8)^{c}$ & $59(7)^{a . b}$ & 0.014 \\
\hline $\begin{array}{l}\text { Psychological } \\
\text { Domain } \bar{x}(\mathrm{sd})\end{array}$ & $62(10)$ & $66(7)$ & $64(9)$ & 0.105 & $62(11)$ & $63(8)$ & $65(9)$ & 0.138 & $62(11)$ & $61(10)$ & $65(9)$ & 0.074 \\
\hline $\begin{array}{l}\text { Social Domain } \\
\overline{\mathrm{x}}(\mathrm{sd})\end{array}$ & $66(16)^{b}$ & $72(14)^{\mathrm{c} . \mathrm{a}}$ & $65(15)^{b}$ & 0.013 & $65(17)$ & $71(14)$ & $69(15)$ & 0.079 & $63(17)^{\mathrm{b}}$ & $70(13)^{\mathrm{a}}$ & $69(15)$ & 0.034 \\
\hline $\begin{array}{l}\text { Environmental } \\
\text { Domain } \bar{x}(\mathrm{sd})\end{array}$ & $62(13)^{b}$ & $66(11)^{\mathrm{a}}$ & $65(14)$ & 0.031 & $61(13)^{b}$ & $66(12)^{\mathrm{a}}$ & $65(12)$ & 0.018 & $59(13)^{\mathrm{b}}$ & $66(12)^{\text {a.c }}$ & $63(13)^{\mathrm{b}}$ & 0.002 \\
\hline
\end{tabular}

PA. Physical Activity. Group A=<30min./day; Group B=30-60min./day; Group C=>60min./day.

Teste Kruskall-Wallis. Post hoc Student-Newman-Keuls.

Table 4. Raw and adjusted odds ratio in insufficiently active subjects in relation to the active subjects according aging male symptoms and quality of life. Florianópolis and São José - SC. 2014. (n=416).

\begin{tabular}{|c|c|c|c|c|}
\hline Variables & $\begin{array}{l}\text { PA level } \\
\text { Raw OR } \\
\text { (CI95\%) }\end{array}$ & $* \mathbf{p}$ & $\begin{array}{c}\text { PA level } \\
\text { Adjusted OR (CI95\%) }\end{array}$ & $* * \mathbf{p}$ \\
\hline Aging male symptoms & & 0.023 & & 0.081 \\
\hline With symptoms & $1.11(1.01-1.22)$ & & $1.08(0.99-1.19)$ & \\
\hline Without symptoms & Reference & & Reference & \\
\hline Overall quality of life & & 0.007 & & 0.021 \\
\hline Good & $0.85(0.76-0.95)$ & & $0.87(0.77-0.98)$ & \\
\hline $\mathrm{Bad}$ & Reference & & Reference & \\
\hline
\end{tabular}

Poisson Regression. * The reference is the insufficiently active.

\section{Discussion}

This study aimed to verify the relation of physical activity with quality of life according to the aging male symptoms in middle-aged men. Physical activity was related to the scores of quality of life of the men, considering that those sufficiently active had higher mean scores compared to insufficiently active, mainly in the physical and psychological fields.

It is observed male population low levels of physical activity are related to a three time greater chance in the impairment of the physical domain and a two time greater chance in the psychological domain (Dey, Gmel \& Mohler-Kuo, 2014). In this way, the fact that most men in this study reach the minimum recommendation of physical activity for health benefits (WHO, 2011) can generate higher mean scores of quality of life.

In the adjusted analysis performed in this study, it was identified that men who perceived their overall quality of life as good, were significantly less likely to be insufficiently active compared to those perceived as bad. Thus, the adhesion to an active lifestyle has been observed to have the influence of a good overall quality of life, regardless of the presence of aging male symptoms.

In addition to the relation with physical activity level, this study also showed relations between quantity and intensity of physical activity with the quality of life of men with aging symptoms. For those men, the practice of physical activity at moderate, moderate+vigorous, and total intensity, superior to $30 \mathrm{~min} /$ day may be related to more favourable characteristics in the social and environmental domains. In the physical domain, these relations seem to be found among those that practiced $>60 \mathrm{~min} /$ day of moderate+vigorous, and total physical activity.

It is necessary to highlight that the physical domain of quality of life encompasses aspects related to physical pain, energy, locomotion, daily life activities, medical treatment, and work (Fleck et al., 1999). According to the study, these aspects may present a certain decline over the years, reflecting in a lower quality of life in this area (Campolina, Dini \& Ciconelli, 2011). This fact justifies the important contribution of physical activity in this period, observed in this study between the men who practiced physical activity with a greater duration $(>60 \mathrm{~min} /$ day). These men presented higher scores on the physical domain of quality of life when compared to those that practiced lower amounts of physical activity (30-60 min/day; $<30 \mathrm{~min} /$ day).

International studies of intervention have shown the positive influence of the physical activity practice at moderate+vigorous intensity of at least $120 \mathrm{~min} /$ week at the physical level of men in distinct health conditions. Benefits for aspects related to the physical domain of quality of life were identified, such as the reduction of pain, fatigue, and improvement of cardiorespiratory fitness (Galvão et al., 2014; Giubilei et al., 2007).

However, studies on aging male symptoms are not found in the national and international literature evaluating the influence 
of physical activity on the quality of life of the men. Thus, comparable results are identified in women who face menopause, equivalent process to the male aging symptoms (Guimarães \& Baptista, 2011a; Fox, Stathi, McKenna \& Davis, 2007).

As regards the results obtained for the social field of quality of life of men with symptoms, studies portray the positive influence of physical activity whereas intensities and specific quantities (Matsudo, 2009; Santana \& Maia, 2009). For women in the menopause period, an analysis carried out in the South of Brazil suggests the practice of at least $60 \mathrm{~min} /$ day of total physical activity for which a significant improvement can be observed in the social field of quality of life (Guimarães \& Baptista, 2011b). Exceeding quantity practiced by men of this study with higher scores in this area (30-60 minutes/day).

The present study, shall see the possibility of influence of male sexual aspect into the social domain of quality of life, since that aspect is one of the factors composing the social domain, including personal relations and social support (Fleck et al., 1999), and it is present in the general of male aging symptoms (Heinemann, 2005). In this way, in male populations above 40 years of age, cross-sectional studies, cohort and quasi-experimental have already considered the importance of physical activity performed at moderate+vigorous intensity for improvement of male sexual aspect, which reflects in higher scores on their quality of life (Kratizik et al., 2009; Revnic, Nica \& Revnic, 2007).

Concerning the quality of life in the environmental domain, similar results were found to those in the social domain, and individuals who practiced 30-60 $\mathrm{min} /$ day of physical activity presented higher scores. It is important to mention that the environmental field is composed of dimensions related to physical security, housing, financial resources, health services, information, leisure, physical environment, and transport (Fleck et al., 1999). Thus, the results concerning the relationship between duration of physical activity and the environmental domain may have an outcome due to some characteristics of the sample. Characteristics which according to some studies influence in the perception of quality of life, and are related to greater physical activity practice, such as higher levels of schooling and socioeconomic class (Beenackers et al., 2012; Finger, Tylleskär, Thomas \& Mensink, 2012).

The literature reports that in some populations was necessary to consider other factors besides physical activity which could influence the quality of life and its different areas (Giannouli et al., 2012; Nakamura et al., 2014). This study found that mainly the of male aging symptoms, schooling, and income can contribute into relations between physical activity and quality of life in the male physical, social, and environmental domains.

It is important to highlight that, although some authors demonstrate the effectiveness of physical activity for the physical, psychological, and social aspects related to quality of life (Cloix et al., 2014; Joseph, Royse, Benitez \& Pekmezi, 2014), there is still a gap in studies investigating the intensity and amount of physical activity for the improvement of the quality of life domains. Especially in the population of middle age men that present male aging symptoms. The already existent evidence in this area is limited to verify the benefits of physical activity for the lower prevalence of symptoms, or the impact on the male quality of life, without however associating the three variables (Corrêa et al., 2014; Salazar et al., 2012). Thus, this study seems to be the first to check in an indirect way the existence of significant relationships between intensity and amount of physical activity, directed to quality of life in the male aging symptoms in middle age.

The results of the present study need to be interpreted with caution, because the sample could not be representative of male population of middle age of the cities of Florianopolis and São José, the final sample did not reach the required minimum according to the calculated sample size. Since the collection was performed in their homes, there was some difficult to contact them, considering that such age group is active in the labour market (40 to 59). When the contact was made after business hours, they often refused to participate in the study by complaint of tiredness after a working day, besides the lack of interest. Other limitations should also be assessed, such as the cross-sectional design that makes it impossible the findings of cause and effect (Lopes, Toledo, Câmara, Menzel \& Santos, 2014).

Concerning the advantages of the study, it is noteworthy the use of a probabilistic sample design, allowing the men of the study to be selected randomly. Still, the use of standardized questionnaires as the scale of the aging male symptoms, being the most used instrument in national and international studies related to the symptoms (Corrêa et al., 2014; Hirokawa, Taniguchi, Fuji, Takaki \& Tsutsumi, 2012), as well as the IPAQ, the most used instrument for evaluation of physical activity in Brazil (Hallal, Dumith, Bastos, Reichert, Siqueira \& Azevedo, 2007), and the WHOQOL, considered one of the main instruments for assessing quality of life (Pucci, Rech, Fermino \& Reis, 2012).

Then, the fact of investigating a theme not portrayed in the literature may enable a greater knowledge of the male health related to quality of life of men who are in the process of aging male symptoms within middle age. As well as encourage the practice of physical activity as a measure aimed at improvements in aspects related to the quality of life of this population in the physical, psychological, social, and environmental domains.

\section{Conclusion}

It is possible to identify the relevance of the practice of physical activity with specific intensity and amount as a means to obtain significant benefits to the physical, social, and environmental domain of male quality of life in middle age presenting the male aging symptoms. Nevertheless, other studies related physical activity to the quality of life in the process of this symptomatology, with randomized longitudinal and/or experimental being necessary, in order to check other important contributions of physical activity for the health and quality of life of men in middle age.

\section{References}

Abdo, C.H.N. \& Afif-Abdo, J. (2007). Estudo populacional do envelhecimento (EPE): primeiros resultados masculinos. Revista Brasileira de Medicina, 74(8), 379-83. 
Andrews, M. (2000). The seductiveness of agelessness. Ageing and Society, 19(3), 301-18.

Antunes, P.C. \& Silva, A.M. (2013). Elementos sobre a concepção de meia idade, no processo de envelhecimento humano. Revista Kairós Gerontologia, 19(5), 123-40.

Beenackers, M.A., Kamphuis, C.B.M., Giskes, K., Brug, J., Kunst, A.E., Burdof, A., \& Lenthe, F.J.V. (2012). Socioeconomic inequalities in occupational, leisure-time, and transport related physical activity among European adults: A systematic review. International Journal of Behavioral Nutrition and Physical Activity, 9. doi: 10.1186/1479-5868-9-116.

Campolina, A.G., Dini, P.S., \& Ciconelli, R.M. (2011). Impacto da doença crônica na qualidade de vida de idosos da comunidade em São Paulo (SP, Brasil). Ciência e Saúde Coletiva, 16(6), 2919-25. http://dx.doi.org/10.1590/S1413-81232011000600029.

Center for Disease Control and Prevention (1999). Behavioral risk factor suveillance system questionnaire. Altanta: CDC.

Cloix, L., Caille, A., Helmer, C., Bourdel-Marchasson, I., FagotCampagna, A., Fournier, C., Lecomte, P., Oppert, J.M., \& Jacobi, D. (2014). Physical activity at home, at leisure, during transportation and at work in French adults with type 2 diabetes: The ENTRED physical activity study. Diabetes and Metabolism, 41(1), 37-44. doi: 10.1016/j.diabet.2014.07.003.

Conceição, M.R., Costa, M.S., Almeida, M.I., Souza, A.M.A., Cavalcante, M.B.P.T., \& Alves, M.D.S. (2012). Qualidade de vida do enfermeiro no trabalho docente: estudo com o whoqol-bref. Escola Anna Nery Revista de Enfermagem, 16(2), 320-25.

Corrêa, L.Q., Rombaldi, A.J., \& Silva, M.C. (2011). Atividade física e sintomas do envelhecimento masculino em uma população do sul do Brasil. Revista Brasileira de Medicina do Esporte, 17(4), 228-31. http://dx.doi.org/10.1590/S1517-86922011000400002.

Corrêa, L.Q., Silva, M.C., \& Rombaldi, A.J. (2014). Associação entre nível de atividade física nos diferentes domínios e sintomas do envelhecimento masculino. Revista Brasileira de Atividade Física e Saúde, 19(2), 186-94. http://dx.doi.org/10.12820/rbafs.v.19n2p186.

Craig, C.L. (2003). International physical activity questionnaires: 12-country reliability and validity. Medicine and Science in Sports and Exercise, 35(8), 1381-95.

Daig, I., Heinemann, L.A.J., Kim, S., Leugwattanakjj, S., Badia, X., Myon, E., Moore, C., Saad, F., Potthoff, P., \& Thai, D.M. (2003). The Aging Males' Symptoms (AMS) scale: review of its methodological characteristics. Health and Quality of Life Outcomes, 1, 77. doi:10.1186/1477-7525-1-77.

Dey, M., Gmel, G., \& Mohler-Kuo, M. (2014). Health-risk behaviors and quality of life among young men. Quality of Life Research, 23(3), 1009-17. doi: 10.1007/s11136-013-0524-4.

Finger, J.D., Tylleskär, T., Lampert, T., \& Mensink, G.B.M. (2012). Physical activity patterns and socioeconomic position: the German National Health Interview and Examination Survey 1998 (GNHIES98). BMC Public Health, 12, 1079-90. doi: 10.1186/1471-2458-12-1079.

Fleck, M.P.A., Leal, O.F., Louzada, S., Xavier, M., Chachamovich, E., Vieira, G., Santos, L., \& Pinzon, V. (1999). Desenvolvimento da versão em português do instrumento de avaliação de qualidade de vida da OMS (WHOQOL-100). Revista Brasileira de Psiquiatria, 21(1), 19-28. http://dx.doi.org/10.1590/ S1516-44461999000100006.
Fleck, M.P.A., Louzada, S., Xavier, M., Chachamovich, E., Vieira, G., Santos, L., \& Pinzon, V. (2000). Aplicação da versão em português do instrumento abreviado de avaliação da qualidade de vida "WHOQOL-bref". Revista de Saúde Pública, 34(2), 178-83. http:// dx.doi.org/10.1590/S0034-89102000000200012.

Fox, K.R., Stathi, A., McKenna, J., \& Davis, M.G. (2007). Physical activity and mental well-being in older people participating in the Better Ageing Project. European Journal of Applied Physiology, 100(5), 591-602.

Freitas, M.C., Queiroz, T.A., \& Sousa, J.A.V. (2010). O significado da velhice e da experiência de envelhecer para os idosos. Revista da Escola de Enfermagem da USP, 44(2), 407-12.

Galvão, D.A, Spry, N., Denham, J., Taaffe, D.R., Cormie, P., Joseph, D., Lamb, D.S., Chambers, S.K., \& Newton, R.U. (2014). A Multicentre Year-long Randomised Controlled Trial of Exercise Training Targeting Physical Functioning in Men with Prostate Cancer Previously Treated with Androgen Suppression and Radiation from TROG 03.04 RADAR. European Urology, 65(5), 856-64. http://dx.doi.org/10.1590/S0080-62342010000200024.

Giannouli, P., Zervas, I., Armeni, E., Koundi, K., Spyropoulou, A., Alexandrou, A., Kazani, A., Areti, A., Creatsa, M., \& Lambrinoudaki, I. (2012). Determinants of quality of life in Greek middle-age women: A population survey. Maturitas, 71(2), 152-61. doi: 10.1016/j.maturitas.2011.11.013.

Giubilei, G., Mondain, N., Minervini, A., Saieva, C., Lapini, A., Serni, S., Bartoletti, R., \& Carini M. (2007). Physical Activity of Men With Chronic Prostatitis/Chronic Pelvic Pain Syndrome Not Satisfied With Conventional Treatments - Could it Represent a Valid Option? The Physical Activity and Male Pelvic Pain Trial: A Double-Blind, Randomized Study. Journal of Urology, 177(1), 159-65.

Guimarães, A.C.A., \& Baptista, F. Atividade física habitual e qualidade de vida de mulheres na meia-idade. (2011a). Revista Brasileira de Medicina do Esporte, 17(5), 305-9. http://dx.doi.org/10.1590/ S1517-86922011000500002.

Guimarães, A.C.A., \& Baptista, F. (2011b). Influence of habitual physical activity on the symptoms of climacterium/menopause and the quality of life of middle-aged women. International Journal of Women's Health, 3, 319-28. doi: 10.2147/IJWH.S24822.

Hallal, P.C., Dumith, S.C., Bastos, J.P., Reichert, F.F., Siqueira, F.V., \& Azevedo, M.R. (2007). Evolução da pesquisa epidemiológica em atividade física no Brasil: uma revisão sistemática. Revista de Saúde Pública, 41, 453-60. http://dx.doi.org/10.1590/ S0034-89102007000300018.

Heinemann, L.A. (2005). Aging Males' Symptoms scale: a standardized instrument for the practice. Journal of Endocrinological Investigation, 28, 34-8.

Heinemann, L.A.J., Zimmermann, T., Vermeulen, A., Thiel, C., \& Hummel W. (1999). A new Aging Male's Symptoms' (AMS) rating scale. Aging Male, 2, 105-14. doi: 10.3109/13685539909003173.

Heinemann, L.A.J., Saad, F., Zimmerman, T., Novak, A., Myon, E., Badia, X., Potthoff, P., T'Sjoen, G., Pöllänen, P., Goncharow, N.P., Kim, S., \& Giroudet, C. (2003). The Aging Males' Symptoms (AMS) scale: update and compilation of international versions. Health and Quality of Life Outcomes, 1(1). doi: 10.1186/1477-7525-1-15

Hirokawa, K., Taniguchi, T., Fujii, Y., Takaki, J., \& Tsutsumi, A. (2012). Job demands as a potential modifier of the association between 
testosterone deficiency and andropause symptoms in Japanese middle-aged workers: a cross-sectional study. Maturitas, 73(3), 225-29. doi: 10.1016/j.maturitas.2012.07.006.

Instituto Brasileiro de Geografia e Estatística (Brasil). (2010). Projeção da população do Brasil/censo 2010. Retrieved from: [http//www. ibge.gov.br].

Joseph, R.P., Royse, K.E., Benitez, T.J., \& Pekmezi, D.W. (2014). Physical activity and quality of life among university students: exploring self-efficacy, self-esteem, and affect as potential mediators. Quality of Life Research, 23(2), 659-67. doi: 10.1007/ s11136-013-0492-8.

Krajewska-Ferishah, K.; Krajewska-Kułak, E., Terlikowski, S., Wiktor, H., Van Damme-Ostapowicz, K., Chadzopulu, A., Adraniotis, J., \& Shpakou, A. (2010). Analysis of quality of life of women in menopause period in Poland, Greece, Belarus and Belgium using MRS Scale. A multicenter study. Advances in Medical Sciences, 55(2), 191-95. doi: 10.2478/v10039-010-0042-3.

Kratzik, C.W., Lackner, J.E., Märk, I., Rücklinger, E., Schmidbauer, J., Lunglmayr, G., \& Schatzl G. (2009). How much physical activity is needed to maintain erectile function? Results of the androx vienna municipality study. European Urology, 55(2), 509-16. doi: 10.1016/j.eururo.2008.02.020.

Lopes, A.C.S., Toledo, M.T.T., Câmara, A.M.C.S., Menzel, H.J.K., \& Santos, L.C. (2014). Condições de saúde e aconselhamento sobre alimentação e atividade física na Atenção Primária à Saúde de Belo Horizonte-MG. Epidemiologia e Serviços de Saúde, 23(3), 305-16. http://dx.doi.org/10.5123/S1679-49742014000300010.

Luiz, M. \& Magnanini, M.M.F. (2000). A lógica da determinação do tamanho da amostra em investigações epidemiológicas. Cadernos de Saúde Coletiva, 8(2), 9-28.

Matsudo, S.M.M. (2009). Envelhecimento, atividade física e saúde. Boletim do Instituto de Saúde, 47, 76-9.

Matsudo, S., Araújo, T., Matsudo, V., Andrade, D., Andrade, E., Oliveira, L.C., \& Braggion, G. (2001). Questionário internacional de atividade física (IPAQ): estudo de validade e reprodutibilidade no Brasil. Revista Brasileira de Atividade Física e Saúde, 6(2), 5-18.

Nakamura, P.M., Teixeira, I.P., Smirmaul, B.P., Sebastião, E., Papini, C.B., Gobbi, S., \& Kokubun, E. (2014). Health related quality of life is differently associated with leisure-time physical activity intensities according to gender: a cross-sectional approach. Health and Quality of Life Outcomes, 12. doi: 10.1186/1477-7525-12-98.

Pardini, R., Matsudo, S., Matsudo, V., Araújo, T., Andrade, E., \& Braggion, G. (1997). Validation of international physical activity questionnaire (IPAQ): pilot study in brazilian young adults. Medicine and Science in Sports and Exercise, 29(6), S5-S9.

Perchon, L.F.G., Pintarelli, V.L., Bezerra, E., Thiel, M., \& Dambros, M. (2011). Quality of life in elderly men with aging symptoms and lower urinary tract symptoms (LUTS). Neurourology and Urodynamics, 30, 515-519. doi: 10.1002/nau.21008.

Pereira, E.F., Teixeira, C.S., \& Lopes, A.S. (2013). Qualidade de vida de professores de educação básica do município de Florianópolis, SC, Brasil. Ciência e Saúde Coletiva, 18(7), 1963-70. http://dx.doi. org/10.1590/S1413-81232013000700011

Pucci, G.C.M.F., Rech, C.R., Fermino, R.C., \& Reis, R.S. (2012). Associação entre atividade física e qualidade de vida em adultos. Revista de Saúde Pública, 46(1), 166-79. http://dx.doi.org/10.1590/ S0034-89102012000100021

Revnic, C.R., Nica, A.S., \& Revnic, F. (2007). The impact of physical training on endocrine modulation, muscle physiology and sexual functions in elderly men. Archives of Gerontology and Geriatrics, 44(11), 339-42.

Rohden, F. (2012). A “criação" da andropausa no Brasil: articulações entre ciência, mídia e mercado e redefinições de sexualidade e envelhecimento. Psicología, Conocimiento y Sociedad, 2(2), 196-219.

Salazar, A., Paravic, T., \& Barriga, O.A. (2012). Percepción de los hombres y sus parejas sobre la calidad de vida en el climaterio masculino. Revista Chilena de Obstetrícia y Ginecología, 77(1), 11-7. http://dx.doi.org/10.4067/S0717-75262012000100003.

Santana, M.S., \& Maia, E.M.C. (2009). Atividade Física e Bem-Estar na Velhice. Revista de Salud Pública, 11(2), 225-36. http://dx.doi. org/10.1590/S0124-00642009000200007.

SBU. Sociedade Brasileira de Urologia (2012). DAEM (Andropausa). Available from: [http://www.sbu.org.br/ publico/?doencas-urologicas\&p=350].

Staerman, F., León, P. (2012). Andropause (androgen deficiency of the aging male): Diagnosis and management. Minerva Medica, 103(5), 333-42.

Waidyasekera, H., Wijewardena, K., Lindmark, G., \& Naessen, T. (2009). Menopausal symptoms and quality of life during the menopausal transition in Sri Lankan women. Menopause, 16(1), 164-170. doi: 10.1097/gme.0b013e31817a8abd.

World Health Organization (2004). Global Strategy on Diet, Physical Activity and Health. Available from:

[http://www.who.int/dietphysicalactivity/strategy/eb11344/strategy_english_web.pdf]

World Health Organization (US). (2010). Global Recommendations on Physical Activity for Health. Available from:

[http://www.who.int/dietphysicalactivity/physical-activity-recommendations-18-64years.pdf]

WHO. World Health Organization. Geneva: World Health Organization. [cited 2012 Sep 19]. MONICA Project. Smoking Questionnaire. Disponível em: Available from: http://www.ktl.fi/publications/ monica/manual/index.htm. Aceddo em: 17 de junho 2014. 


\section{Author's note}

Melissa de Carvalho Souza is Master of The Graduate Program in Human Movement from the Universidade do Estado de Santa Catarina (UDESC).

Adriana Coutinho de Azevedo Guimarães is $\mathrm{PhD}$ Professor of the Department of Physical Education at the Center for Health Sciences and Sports from the Universidade do Estado de Santa Catarina (UDESC).

\section{Corresponding author}

Melissa de Carvalho Souza

Laboratório de Pesquisa em Lazer e Atividade Físca (LAPLAF); Centro de Ciências da Saúde e do Esporte (CEFID); Universidade do Estado de Santa Catarina (UDESC).

Rua Pascoal Simone, 358, Coqueiros. Florianópolis, SC, Brazil.

Email: mecarvalho.s@gmail.com

Manuscript received on November 12, 2015

Manuscript accepted on January 24, 2016

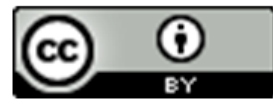

Motriz. The Journal of Physical Education. UNESP. Rio Claro, SP, Brazil - eISSN: 1980-6574 - under a license Creative Commons - Version 3.0 